\title{
A Qualitative Review of Cruise Service Quality: Case Studies from Asia
}

\author{
Yeohyun Yoon ${ }^{1}$ (D) and Kyoung Cheon Cha ${ }^{2, *}$ \\ 1 School of Hotel and Tourism Management, Youngsan University, Busan 48015, Korea; \\ yeohyun.yoon@gmail.com \\ 2 Department of Business Administration, Dong-A University, Busan 49236, Korea \\ * Correspondence: kccha@dau.ac.kr
}

Received: 2 September 2020; Accepted: 29 September 2020; Published: 30 September 2020

\begin{abstract}
Although the cruise sector is considered an 'unreplaceable' form of tourism, with the cruise industry recording steady growth over the years, there is a lack of research and analysis on cruise ships themselves. Accordingly, this study sought to determine whether service quality differences among ships operating in the Asian market could suggest broader implications for the sustainability of the cruise industry. We chose the SERVQUAL framework for the analysis; we also employed the multiple case study method and topic synthesis to compare the service quality of three ships. Of the ships investigated-the Costa Victoria, Diamond Princess, and Superstar Virgo-the Diamond Princess had the highest service quality. Based on the results, we outlined suggestions for improving the quality of cruise services, including introducing the latest large ships and high-tech facilities, complying with the departure and arrival times of sailing schedules, improving the ratio of crew members per passenger, establishing a cruise personnel training system, and expanding membership program operations.
\end{abstract}

Keywords: cruise; service quality; SERVQUAL; onboard attributes

\section{Introduction}

Cruise tourism is one of the fastest growing tourism segments, and it has undergone significant transformation, especially in the last few decades [1,2]. Since 1990, the average annual passenger growth has reached about $6.63 \%$, with cruise tourists increasing from 7.21 million in 2000 to 26.86 million in 2019 [3]. The number of passengers originating from Asia hit a record high in 2017, with 4.052 million taking ocean cruises (up 20.6\%), and Asian cruise passenger numbers hit another record high in 2018 with 4.24 million (up 4.6\%). In 2018, there were 28.5 million global ocean passengers, $14.8 \%$ of which were from Asia (versus $15.1 \%$ in 2017) [4]. The five-year compound annual growth rate (CAGR) of Asian port calls from 2014 to 2019 was 14\%, and the five-year growth during that time was $88 \%$, continuing an upward growth trajectory. Destinations such as Japan, mainland China, the Philippines, Indonesia, and India will show a stronger five-year CAGR and five-year growth than Asia's average [5]. It is time to learn more about the rapidly growing Asian cruise market.

Some believe that the expansion of disposable income and increased interest in quality of life have contributed to the steep growth of the cruise industry. Most cruise tourists are repeat customers who have had a satisfactory cruise experience and become loyal to a specific cruise brand [6,7]. The continued expansion of cruise passengers is also due to the provision of high-value cruising through the newest ships, world-class destinations, innovative ship facilities, and various onboard activities. Cruise lines design various services to meet changing customer needs $[8,9]$. High-value cruising refers to various special services, including cabins with excellent amenities, restaurants with various dining options, spas and wellness programs, sports and fitness, meeting rooms, Kids Zones, and wedding 
packages. Cruise ship service innovation has made cruise vacations more attractive and available to more target markets [8]. Cruise lines should create sustainable demand and loyal customers by differentiating the service quality of the onboard experience. Research by Li and Petrick [10] demonstrated that customer retention should be improved by providing excellent service quality and unique experiences.

Academic research in the cruise field has led to quantitative and qualitative growth since 2010 [11]. Papatnassis and Bekmann analysed papers published in a total of 56 overseas academic journals from 1983 to 2009 and divided them into four categories according to their research subjects. They found that despite the diversity of research methods and topics, scholars tend to focus on business, management, and economics. Vega-Muñoz et al. [12] analysed 320 papers in 142 journals between 1980 and 2018 and determined that the cruise industry is a subject of research worthy of various approaches. Cruise tourism research has been fragmented because of its multidisciplinary nature and its relatively young status [13]. Moreover, quantitative studies covering quality of service, service attributes, and perceived value $[8,10,14-17]$ have been conducted, and a qualitative approach to these variables has also been taken. In addition, qualitative research into cruise lines has been conducted on limited topics such as brands, crisis management, and corporate sustainability [18-21].

The sustainability of the cruise industry has attracted strong scepticism, with discussions centred on its corporate social responsibility, environmental issues, economic contributions, and adverse effects on the port of call [22-25]. As customers are increasingly interested in the ethical and environmental aspects of products and services [26], many scholars believe that the future challenges of the cruise industry are related to sustainable development $[23,27]$. The Cruise Line International Association (CLIA) [28] is committed to contributing to the port of call in the form of 'partnerships with the local governments, staggered arrivals and departures, excursion diversification, shoreside power, and local passenger spending'. It is encouraging cruise lines to invest more than USD 22 billion in energy-efficient ships and technologies in order to achieve the goal of reducing carbon emissions by $40 \%$ by the year 2030, as compared to 2008 emission levels. In particular, the cruise industry [25], which is already in a crisis due to the COVID-19 pandemic, must 'improve its service process to improve its reputation' [29]; accordingly, it should seek to enhance its image through improved service quality, develop innovative management systems and strategies, and promote sustainability.

This study aims to examine cruise service quality. First, target ships operating in Asia with similar ship characteristics were selected for an in-depth understanding of cruise service quality. The 'cruise SERVQUAL' derived from Parasuraman et al.'s [30] SERVQUAL model (Tables 1 and 2) is used to compare the service quality of Asian-operated ships. This study does not intend to scientifically verify cruise SERVQUAL, but it is an attempt to understand cruise service quality from these dimensions. As a result, this study draws a model of cruise SERVQUAL based on the literature and applies it to actual ship cases to compare service quality. This is done to understand the service environment through cruise attributes that affect passenger choice and to provide practical implications for sustainable cruise service quality.

\section{Literature Review}

\subsection{Cruise Service Quality}

Service quality is recognized as a key determinant of business success and a major method of gaining competitive edge. With the rapid increase in the capacity of the cruise industry, cruise lines should reconsider differentiation [24], and as service quality is an important variable in creating customer loyalty, it is important to derive a service improvement strategy by measuring service quality.

According to Parasuraman et al., service quality is defined as a 'the consumer's judgment about an entity's overall excellence or superiority' of the service; the authors use the concept of 'perceived service quality', which differs from objective quality [30]. Perceived quality, unlike objective or practical quality, is more abstract than specific product properties and similar to attitude; it is an overall evaluation 
by the customer. Parasuraman et al. [30] proposed SERVQUAL (see Table 1) as a perceived service quality measurement tool. Their SERVQUAL model adopts a disconfirmation paradigm in which the quality of service consists of five dimensions: reliability, responsiveness, empathy, assurance, and tangibles. Many researchers have tried to transform service quality to suit the hospitality and tourism environment [31], testing the SERVQUAL framework in restaurants [32], lodging [33], destinations [34], and outbound guide package tours [35]. Industry-adjusted measures include HISTOQUAL for historic houses [36], ECOSERV for eco-tourism service quality [37], and Cruse's SERV-PERVAL [15] to measure holiday experience satisfaction (HOLSAT) [38].

Table 1. SERVQUAL Model.

\begin{tabular}{cl}
\hline Dimension & Contents \\
\hline Tangibles & Physical facilities, equipment, and appearance of personnel \\
Reliability & Ability to perform the promised service dependably and accurately \\
Responsiveness & Willingness to help customers and provide prompt service \\
Assurance & Knowledge and courtesy of employees and their ability to inspire trust and confidence \\
Empathy & Caring, individualized attention the firm provides its customers \\
\hline &
\end{tabular}

In an empirical study of Caribbean cruise passengers by Petrick, four measurement items (excellent quality, reliability, dependencies, and consistency) of SERV-PERVAL, a concept that emphasizes the reliability items in the SERVQUAL model, were used. The most suitable model for predicting behaviour was the quality model, rather than the satisfaction model or perceived value model [15].

Kwortnik [21] expanded 'Bitner's service scope framework' [39] by analysing customer data on an online cruise discussion board (CruiseCritic.com) to investigate the impact of cruise line service environments, specifically considering passengers' emotions, meaning-making, and onboard behaviours. The physical environment of a ship, called the shipscape, was divided into (a) ambient environmental factors (scents, sounds, cleanliness, lighting, music, temperature, etc.); (b) design elements (decoration, colour, furnishings, layout, size, entertainment architecture, etc.); and (c) social factors (crowding, queues, cruise cues, crew co-working production, and friendship). Cruise customers who primarily pursue emotional enjoyment are consciously and unconsciously observing the environmental factors of cruise ships [21], and these physical environments will be important determinants of customer psychology and behaviour [40].

Lobo used the SERVQUAL scale of [30] for luxury cruise line passengers to measure the difference between expectation and performance of service quality and to explore the relationship between overall satisfaction and behaviour [41]. Li and Petrick empirically verified the impact relationships among quality, value, satisfaction, investment size, and alternatives on online panels of cruise experiences that affect customer loyalty [14]. Petrick analysed differences in cruise experiences, price sensitivity, monetary price, behavioural price, perceived quality, perceived value, overall satisfaction, word of mouth, and repurchase intention by segmenting Caribbean cruise passengers according to their perceptions of the cruise line's reputation [42]. Yi et al. [43] explored Asian cruise travellers' perceived value, in terms of satisfaction and behavioural intention, of the travel experience. The perceived value was measured on a SERV-PERVAL scale, and the results of the study showed that the perceived value of the cruise experience affects travel satisfaction and behavioural intention [43]. Chua et al. [8] used the three dimensions of service quality form developed by Brady and Cronin [44], where cruise service quality is divided into three dimensions: physical environment (physical surroundings of cruise ships), interaction (employee service), and outcome quality (benefits given to customers at a service encounter). They analysed the relationship between novelty, perceived value and satisfaction, and loyalty [8].

The quality of an interaction represents the customer's perception of crew service in service delivery [45], and the interaction between the customer and the crew is reflected in 'Service Performance', in which the customer evaluates the service experience [46]. Interactional quality can be measured with 
assurance (knowledge, employee courtesy, and ability to build customer trust), responsiveness (service delivery and willingness to help customers), reliability (employee's ability to accurately perform promised services), and empathy $[30,44,45,47]$. Outcome quality is the technical quality that determines the perceived service quality by what cruise customers received during service delivery [44]. Even though SERV-PERVAL [15] applies SERVQUAL to the cruise industry and emphasizes perceived value, this study focuses on SERVQUAL [30] because it is more commonly used.

\subsection{Cruise Service Attributes}

Since service quality is an overall evaluation of service attributes provided by suppliers [48], consideration of cruise service attributes is necessary when dealing with cruise service quality. Figure 1 shows cruise service divided into service before boarding, during boarding, and after disembarking, and categorized into the supplier processes, encounter processes, and customer processes. Most of the services before boarding and after disembarkation are excluded because they are outside the scope of this study as they often involve travel agencies that make cruise product reservations. Onboard cruise processes are shore excursions, dining, entertainment, cabin comfort, safety on board, sports facilities, shopping facilities, and embarking and disembarking procedures. Customer processes are efficiency of food and beverage service crew, safety announcements, efficiency of (dis)embarkation crew, and efficiency of cabin crew. Onboard cruise support is sending cruise information, providing information, the presence of crew members, shore excursion booking, and the provision of quality entertainment and meals [49].

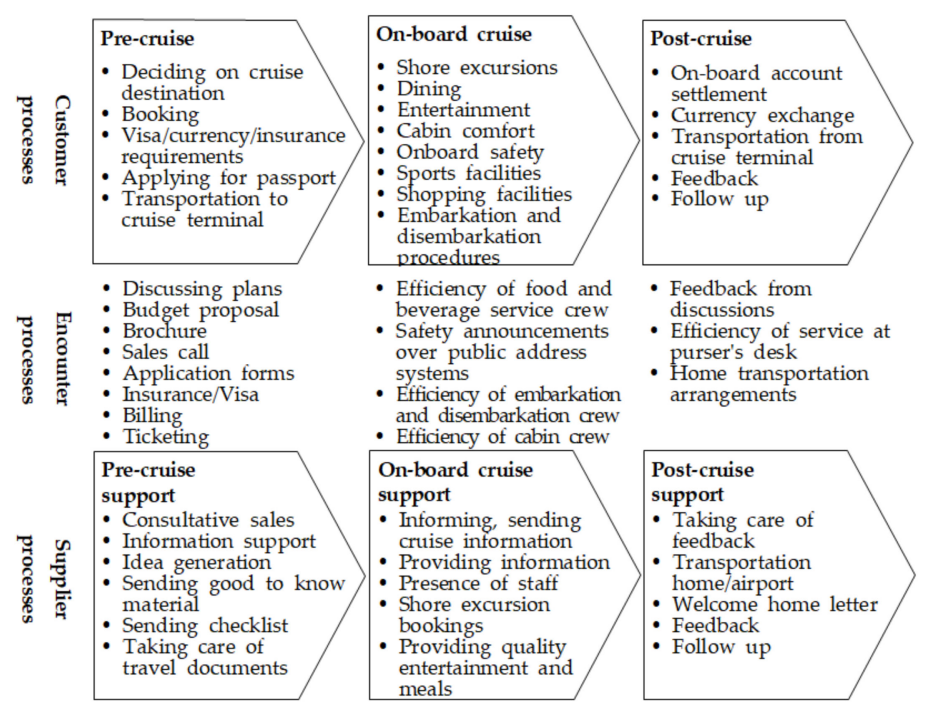

Figure 1. Example of passenger, cruise company, and encounter processes mapping [49].

Petrick et al. investigated the attributes that influence the evaluation of passenger cruise experience, including service, crew, food and beverage, entertainment/activity, ship facilities, port of call, children/youth issues, cabin, price, policy, and safety [50]. In addition, the Cruise Line International Association (CLIA) conducted a consumer cruise lifestyle trend survey, which revealed that accommodation, cuisine, entertainment, spa/wellness, and coastal travel are important to consumers when choosing a cruise vacation [51].

According to Anderson's Information Integration Theory, the perceived product performance of various attributes jointly determines tourists' overall attitude [50]. Xie et al. [52] presented onboard attributes that influence the decision-making of current and potential cruise customers. Potential customers value recreation and sports attributes (sports platform, wall climbing, miniature golf, and ball facilities), supplementary attributes (library, internet café, business centre, and laundry), fitness and health attributes (spa, fitness centre, beauty salon, and swimming pools/hot tubs/whirlpools) 
significantly more than existing customers. Although there were no significant differences between current and potential customers in the value placed on entertainment, core attributes (e.g., cabin, restaurants, food, room service), children's attributes, and crew attributes, potential cruisers valued social gathering and current cruisers valued crew service significantly [52].

Whyte [13] explored the cruise attributes of onboard environment, onboard social interaction, and onboard recreation and analysed their relative importance. The onboard environment includes cleanliness, good appearance of ships and facilities, comfortable environment, safe environment, high-quality food and restaurants, relaxed and stress-reducing atmosphere, high-quality accommodation, private space, variety of food and restaurants, and uncrowded onboard environment. Social interactions include opportunities to meet new people, socializing with other passengers, passenger groups with diverse demographic characteristics, and passenger-friendly attributes. Onboard recreation includes excellent swimming pools and hot tubs, health and wellness facilities and amenities, exciting atmosphere, and entertainment facilities and atmosphere [13].

\section{Method}

\subsection{Research Flowchart}

This study proceeded as detailed in Figure 2. First, cruise lines and ships were selected for the study. The cruise SERVQUAL was derived by examining representative SERVQUAL models and the existing literature dealing with cruise service quality. The three selected cruise ships were then analysed by comparing them along the five dimensions of the cruise SERVQUAL.

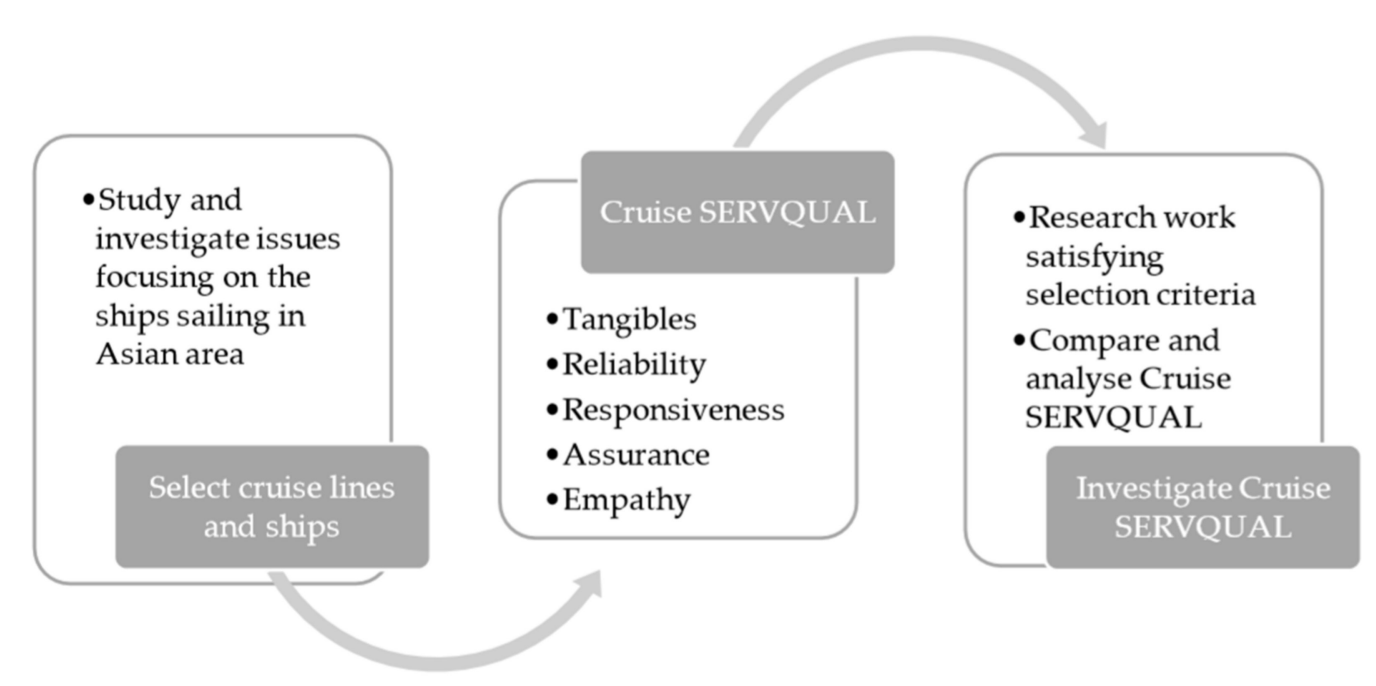

Figure 2. Research flowchart.

\subsection{Objectives and Method}

This study explored the differences between three cruise ships operating in the Asian market in terms of their service quality, which is a core competitive advantage in the cruise industry.

The qualitative case study method is a research approach that explores complex phenomena in context using a variety of data sources. This allows the problem to be explored not only through a single lens, but to reveal and explore several aspects of the phenomenon [53]. Despite the scepticism of some scholars toward case studies, the method is widely used because it can provide insights not available with other approaches. As Eisenhardt [54] noted, case studies are 'particularly well suited to new research areas or research areas for which existing theory seems inadequate'. Rowley [55] stated that '[c]ase studies are one approach that supports deeper and more detailed investigation of the type that is normally necessary to answer how and why questions'. James et al. [56] compared two Arctic cruise destinations with contrasting growth profiles and studied them by employing a multi-case study 
method with a focus on stakeholders' awareness and management of cruise tourism sustainability, while [22] analysed corporate sustainability strategies around the cruise and shipping industries in the context of the United Nations' 17 sustainable development goals. Leposa [57] investigated cases of cruise tourism, ecological tourism, and region-based tourism research in marine protected areas and presented important examples of social sustainability. Case studies have been widely used in recent years in certain areas of cruise tourism. Moreover, the lack of qualitative research on cruise service quality necessitates in-depth investigation, and case studies were judged to be an appropriate research method for this purpose.

This study was conducted in accordance with the following research process proposed by [58]. The first step was the 'formulation of the research question and the selection of the theories to be tested'. We defined the research question as follows: Can service quality differences between ships operating in the Asian market suggest broader implications for the sustainability of the cruise industry? We then selected the service quality model SERVQUAL as the theory to be tested. The next step was the '[i]dentification of the case study where the competing theories can be tested, and selection of the data collection and analysis methods'. To compare the three vessels, the 'multi-case study' method was chosen to complement the 'thematic synthesis' (i.e., searching, selecting, extracting, and thematically synthesizing) proposed by [59]. The next step was the '[a]nalysis of the case and formulation of the patterns of testable hypotheses/predictions of the future case development based on the foundations provided by the theory'. The cruise service quality model was derived from SERVQUAL as an analysis frame. This was followed by the ' $[\mathrm{f}]$ ormulation of criteria for outcome evaluation'. The final step was 'a follow-up research that will be conducted in a set period of time to evaluate the case outcomes versus the propositions/hypotheses formulated in Step 1'. Itemized improvements were derived from the service quality of the three ships.

In case studies, the researcher performing the data collection must be able to ask good questions as well as listen to the answers and interpret them accurately. Therefore, data collection and the execution of case studies are crucially dependent on the researcher's capabilities. In other words, it is essential to accurately grasp the case study questions and suggestions and to be able to approach the study in a flexible manner without being biased [55]. Therefore, in this study, one marketing professor with abundant research experience in the marketing field, one working expert with over 15 years of experience in the cruise industry, and one hotel tourism professor who is experienced in collecting and interpreting qualitative research data in the hospitality industry participated in the analysis. The analysis process was reviewed by professors at Youngsan University, who all had expertise in qualitative research, methodology design and content.

The use of multiple case studies allows researchers to explore differences within and between cases. The goal is to replicate the findings of the study across multiple cases. Since comparisons are drawn, it is essential to carefully select cases so that researchers can predict whether cases will have similar outcomes or contrasting outcomes based on theory [60].

This study focused on the Carnival Corporation (Costa Cruises, Princess Cruises), which holds the highest market share in the global cruise market, and Star Cruises (Genting Hong Kong), which has established itself as a leader in the Asian market. According to 'Asia-Pacific Market Briefing' (Cruise Industry News) [61], as of 2015, Star Cruises ranked first as a sole brand at 29.9\%, while the total market share of all Carnival Corporation brands (Costa, $\mathrm{P} \& \mathrm{O}$, Princess, and Carnival) was $40.6 \%$, ranking it first as a company. The data predicted that Star Cruises would add two ships in 2021, taking its market share to $42.3 \%$, which will not only be the highest among single brands but is also higher than the market share of all Carnival Corporation brands combined (30.5\%). These companies are representative cases of successful cruise companies and are judged to be valuable as research targets since they represent the overall trend of the cruise industry. Especially during the COVID-19 pandemic, when differentiation is essential in light of the overall suppression of tourism, comparisons between the global market leader, Carnival, and its fierce rival Star Cruises in the Asian market could have 
implications for the overall management and service operation of the cruise industry, particularly in Asia.

In the process of selecting case study objects, access to data is essential, meaning that it is easy to obtain interviews, observations, records, or various data [60]. It was easier to collect data from the home pages of these companies than those of other companies; available information included various reports, internal company data, books, and academic papers. In addition, the results could be supplemented through in-depth interviews with a group of experts with extensive experience in cruise tourism.

Comparative research helps to clarify the definition of a research problem and address contextual factors with conceptual equivalents. Differences and similarities between cases can only be established if equivalence has been secured at various levels. Equivalence at the level of constructs, measurements, samples, and administration is emphasized [62]. For comparison, Costa Victoria, Diamond Princess, and the Superstar Virgo were selected as the three ships of study, which were representative of ships operating in the Asian market and were conceptually equivalent in terms of their overall 'ship facts', as outlined in the next section.

\section{Result}

\subsection{Cruise SERVQUAL}

The theoretical analysis framework for the research subject was based on 22 items in the five dimensions of the SERVQUAL model. However, since the SERVQUAL model does not reflect the special environment of cruise ships, Cruise SERVQUAL was set, as shown in Table 2. It considers cruise properties and service processes as defined in the existing literature.

Table 2. Cruise SERVQUAL.

\begin{tabular}{|c|c|c|}
\hline Dimensions & Cruise SERVQUAL & Reference \\
\hline Tangibles & $\begin{array}{l}\text { (1) Ship Facts: Cruise ship's facilities have up-to-date equipment. } \\
\text { (2) Ship's interior style, cabin, cleanness: Cruise ship's facilities are } \\
\text { visually appealing. } \\
\text { (3) Crew members' appearance: Crew members are well-dressed } \\
\text { and appear neat. } \\
\text { (4) Service materials, other cruise guests: The appearance of the } \\
\text { physical facilities of cruise ship is in keeping with the type of } \\
\text { services provided. }\end{array}$ & {$[10,14,15,21,30,41,52]$} \\
\hline Reliability & $\begin{array}{l}\text { (1) Itinerary and departure/arrival time compliance: When the cruise } \\
\text { ship promises to do something by a certain time, it does so. } \\
\text { (2) When customers have problems, the cruise ship is sympathetic } \\
\text { and reassuring. } \\
\text { (3) Cruise ship is dependable. } \\
\text { (4) Cruise onboard programs are on time: Cruise ship provides its } \\
\text { services at the time it promises to do so. } \\
\text { (5) Cruise ship keeps its records accurately. }\end{array}$ & {$[13,15,30,41-43,49,52]$} \\
\hline Responsiveness & $\begin{array}{l}\text { (1) They do not tell customers exactly when services will be } \\
\text { performed. } \\
\text { (2) You do not receive prompt service from crew members. } \\
\text { (3) Crew members are not always willing to help customers. } \\
\text { (4) Crew members are too busy to respond to customer requests } \\
\text { promptly. }\end{array}$ & {$[13,14,21,30,41,43,49,52]$} \\
\hline Assurance & $\begin{array}{l}\text { (1) Customers can trust crew members. } \\
\text { (2) Announcements for safety and lifeboat drills: Customers feel safe } \\
\text { in their transactions with crew members. } \\
\text { (3) Crew members are polite. } \\
\text { (4) Crew members get adequate support from cruise lines to do their } \\
\text { jobs well. }\end{array}$ & {$[8,13,30,41,43,49,52]$} \\
\hline
\end{tabular}


Table 2. Cont.

\begin{tabular}{lll}
\hline Dimensions & \multicolumn{1}{c}{ Cruise SERVQUAL } & Reference \\
\hline & (1) These cruise lines do not give customers individual attention. & \\
& (2) Crew members of cruise lines do not give customers personal \\
attention. & \\
(3) Crew members of cruise lines do not know what customer's & \\
needs are. & (4) These cruise lines do not have customer's best interests at heart. \\
& $\begin{array}{l}\text { (5) These cruise lines do not have operating hours convenient to all } \\
\text { their customers. }\end{array}$ \\
\hline
\end{tabular}

Variant SERVQUAL of [30] for cruise service environments.

\subsection{Cruise SERVQUAL Investigation}

\subsubsection{Tangibles}

Tangibles are the physical proof of service. For cruise ships, these are 'ship facts', for example, interior, cabin and sanitation, crew attire and appearance, and other customers on board. In the case of the Costa Victoria, service began after the ship was built in 1996, the balcony cabin was expanded in 2004, and public facilities and cabins were modernized in the Italian style in 2013. Up to 1928 passengers are serviced by 790 crew members throughout 12 floors. This ship operates five restaurants, three swimming pools, Jacuzzi, bars and lounges, a casino, a disco club, a jogging track and sports court, a spa and beauty salon, a fitness facility, and a solarium. In addition, there are libraries, laundry facilities, shopping centres, photo shops, chapels, and conference rooms where business meetings can be held. Princess Cruise's Diamond Princess was launched in 2004. The company invested USD 30 million (about KRW 34.9 billion) in 2014 to repair the ship, followed by another renovation in 2017. It has a maximum capacity of 2706 passengers and a total of $1100 \mathrm{crew}$ members aboard. It contains nine restaurants, four swimming pools, five bars and lounges, an art gallery, library, casino, grand theatre, fitness centre, spa, beauty salon, teen lounge, golf putting course, youth centre, and Japanese-style sauna (bath). Star Cruise's Superstar Virgo has been in service since 1999 and was constructed in 1996. Renovations were made to install mega water slides in 2009, and the ship was modernized with art ship designs in 2012. It has nine restaurants, five bars, two swimming pools, a Jacuzzi, a mega water slide, a golf practice range, a mini-golf putting course, a basketball court, a whirlpool, a sauna, a casino, and a duty-free shop [63-65].

Compared to other voyage regions, the ships operating in Asia, such as the Costa Victoria and Superstar Virgo, are older. In particular, the oldest of Costa's cruise ships are operating on Asian schedules. Fortunately, what is encouraging is that the renovation of various auxiliary facilities was conducted recently (2012-2014). In particular, mega (jumbo) ships with colourful entertainment facilities in other areas, such as the Mediterranean Sea and Caribbean, have been slow to deploy, but the recent introduction of Royal Caribbean Cruise's new Quantum of the Seas and Dream Cruise's Genting/World Dream on Asian routes have given Asian cruise passengers a wider choice of cruise ships. In addition, Costa has announced orders for a mega cruise ship with a maximum capacity of 6600 passengers, capable of accommodating about 300 more passengers than Royal Caribbean Cruises' Oasis class, and Princess also announced a 140,000-tonne Majestic Princess Asia. Gradually, competition among the newest large ships in the Asian market is expected to sharpen.

For the interior of the cruise ship, Costa Victoria stands for authentic Italian style, while the Concord Plaza, indoor pool, and Pompeii Spa embody a concept that combines European elegance with American sophistication. It is decorated with bright wood-toned furniture and soft pastel-toned decorations, and the cabin size is rather narrow, $14-45 \mathrm{~m}^{2}$ (145-475 sq. ft.). In particular, Costa Victoria is a vessel that pursues artistic beauty with glass mosaics designed by masters of architecture and aesthetics. The Diamond Princess is a premium ship built in Japan and decorated with millions of 
dollars in art collections. It has a wide space with a modern and luxurious interior, so it is cosy and elegant. It boasts various auxiliary facilities and spacious cabins. Cabins with balconies account for $55 \%$ of all total cabins, which is larger than other ships, and the cabin size is $15.6 \sim 123.5 \mathrm{~m}^{2}(168-1329$ sq. ft.). The Superstar Virgo is a flagship of Star Cruise that provides an oriental cruise experience. It is decorated with colourful oriental-style decorations, and the cabin size is $12-60 \mathrm{~m}^{2}(129.81-650.25 \mathrm{sq}$. $\mathrm{ft}$.). Calculating the passenger space ratio (PSR) based on the ratio of the total tonnage of the cruise ship and the number of passengers, the scores for the Costa Victoria, Diamond Princess, and Superstar Virgo are 31.4-39, 35.7-42.8, and 26.9-38, respectively. The Diamond Princess has the largest occupancy space per passenger, making it a comfortable cruise [63-66].

The U.S. Centers for Disease Control and Prevention (CDC) introduced the Vessel Sanitation Program (VSP) for the purpose of controlling the introduction, propagation, and spread of diseases on board ships and considers ships that have scored more than 86 out of 100 points to be hygienic and safe from disease. The VSP was established in close cooperation with the cruise industry in order to provide a 'safe, healthful environment for all passengers at sea' [66]. Cruise ship crews are trained in sanitation and health practices, and ships undergo unannounced inspections twice a year, which determine their scores. The CDC score was 96 points for the Costa Victoria and 98 points for the Diamond Princess, while the Superstar Virgo was not investigated [67]. However, in the case of the Costa Victoria, which was rated as a hygienic and safe vessel, passengers reported serious hygiene problems such as bedbugs, fleas, and cockroaches crawling in the cabin during the 2016 trip chartered by Korean travel agencies. In the large and complex structure of cruise ships, complete extermination of pests such as bedbugs and fleas is virtually impossible, so specific and detailed guidelines and efforts are required to prevent any cases of pests from appearing on the ship. The Diamond Princess cruise ship has been docked at the port of Yokohama, Japan since 3 February 2020. A total of 691 cases of coronavirus 2019 (COVID-19) infection have been identified as of 23 February. Those who tested negative for the virus or had no symptoms were advised to immediately leave the vessel because the infection was assumed not to have spread to them. On 5 February, however, the government mandated a 14-day health monitoring period, citing the severity of the infection. Passengers identified as free of infection finally began disembarking on 19 February [68]. In Australia, the cruise ship Ruby Princess has become the largest COVID-19 epicentre. When Ruby Princess arrived at Sydney Harbour in New South Wales on 19 March, 2020, approximately 2700 passengers disembarked. By 24 March, approximately 130 of the passengers tested positive for COVID-19, increasing to 162 on 27 March [69].

Recently, the CDC announced an extension of a No Sail Order for all cruise ships. Through 'Interim Guidance for Ships for Managing Suspected or Confirmed Cases of Coronavirus Disaster 2019', detailed quarantine response guidelines were announced, including pre-boarding procedures and an onboard cruise crew and ship operator to manage infection cases [70]. Despite these measures, it remains undeniable that the COVID-19 pandemic has brought the global cruise industry to a halt. However, since most people are still confident about the future of the cruise industry, they remain optimistic that the impact of the epidemic on the cruise market will be minimal [29].

Most crew members on the Costa Victoria are from Southeast Asia, while most members at the manager level are Europeans. Since the style concept and main passenger group are European and Asian, there are multinational crews that speak English and German, and Asian routes include a large number of Asian crew members, especially Chinese-, Japanese-, and Korean-speaking crew members. The Diamond Princess operates in the Asia-Pacific region, with a high proportion of Australian and New Zealand nationals and Asians, especially Japanese nationals, and a significant number of North American nationals. Most crew members are Asian, American, or European. Star Cruise passengers are mostly Asians from China, India, Malaysia, and Singapore, and Asian nationals, including crew members from China, the Philippines, India, and South Korea, account for a large portion of most departments, except for navigation.

Costa, Princess, and Star Cruises all give standard qualifications for attire and appearance when hiring cruise crew members, and, in principle, members are required to wear different uniforms 
for different job positions, along with name tags with 'the name and nationality of the crew, the department in charge'. In addition, crew members have detailed regulations on hair styles and dyeing, nails, makeup, tattoos, piercings, accessories, shoes, and uniforms, and supervision is conducted accordingly [71-73]. The nationality and language fluency information of the crew is an especially important factor on cruise ships with multinational passengers.

On cruise ships, a Seapass is used as a passenger's ID card, cabin key, and means of payment (as a credit card) for purchases. The shipboard card contains the passenger name, sailing information (ship name as well as boarding and sailing dates), and the cabin number. The personal information of the passenger is entered in advance when booking or boarding is registered. In addition, on the Costa Victoria, information on the operation of the ship's programs and facilities is posted through the shipboard newspaper, called Costa Today, which is translated into Chinese, Korean, Japanese, English, Italian, French, German, and Spanish, and it offers recent charter events in Korea and China. The Diamond Princess's newspaper is Princess Patter, which is printed in English and Japanese. The Superstar Virgo offers translations of its Star Navigator in English, Chinese, Korean, and Japanese. As such, service forms such as shipboard cards, shipboard newspapers, and notices are provided in appropriate languages, designs, and formats that consider all ship passengers [63-65] (Table 3).

Table 3. Tangibles.

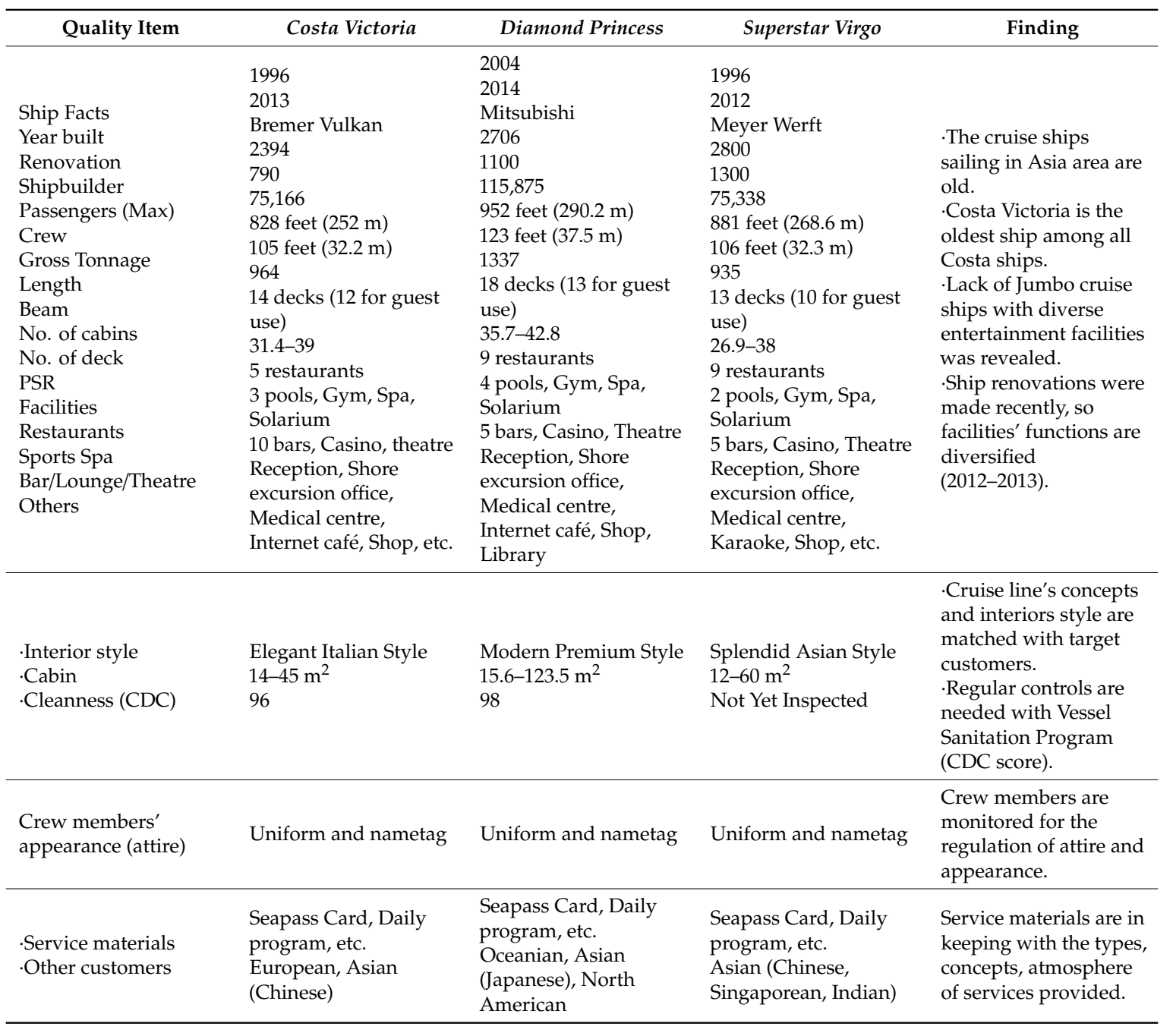




\subsubsection{Reliability}

Reliability relates to consistency and dependability of performance. This means that the entity executes consistent services correctly, which relates to the trustworthiness and honesty of the crew during customer contacts, and to whether the company respects its commitments and is capable of thorough performance. For the cruise industry, reliability is related to the correct arrival being made according to the schedule announced in advance, the crew's level of willingness to solve problems, passenger belief in the ship operator, compliance with the facility and program operation hours, and maintaining the passenger record accurately (Table 4). The passenger-crew ratios (PCRs) for the Costa Victoria, Diamond Princess, and Superstar Virgo are 2.8:1, 2.5:1, and 2.2:1, respectively, indicating that the service quality of the Superstar Virgo, which has one crew member per 2.2 passengers, is expected to be higher. A higher crew ratio results in better service [63-66].

The cruise schedule is announced through Cruise Log, delivered to each cabin on the day of boarding, and if it is impossible to enter the port due to external variables, such as bad weather or terrorism, the schedule may be changed under the authority of the captain. Costa Victoria states in the terms and conditions that it has the right to change the cruise program or the sailing schedule at any time for a valid reason, and it is not responsible for the cost to passengers. Since cruise lines are not responsible for weather or sea conditions, they do not have an obligation to compensate for changes in schedules, omissions of a port, or replacement of the port during the voyage. Princess Cruise guarantees a full refund if the cruise is cancelled, altered, or delayed for any reason, and if it is cancelled before the departure date, it provides accommodation and meals at no additional cost. If the departure port is changed, transportation from the existing port to the new port is provided, and if the sailing schedule is terminated early, passengers will receive these days as future cruise credit. Star Cruises says they have the right to change destinations, schedules, prices, and programs without prior notice for any reason [63-65].

However, after the 2015 Superstar Libra schedule was cancelled due to strong winds and replaced with $\mathrm{Da}$ Nang, the entire cost of the port tour was refunded and the onboard credits (used like cash on board) were provided at RMB 240 each. Even when the one-night cruise schedule in Hong Kong was changed to a two-night and three-day schedule before departure in 2013, a full refund or two-night schedule without any additional cost was announced. When Costa Victoria's 2014 sunken barge blocked the port and prevented it from entering Harong Bay port, passengers were given USD 50 per cabin in onboard credit, but a considerable number of passengers protested, demanding higher refunds [74].

The problems passengers may experience on cruise ships include 12 areas: baggage, cabin life, dining, shore excursions, services, scheduling, health, communication, spa, billing, crime, and safety. Examples include conversion of bed type in cabin, exchange of amenities in cabin, change of TV or toilet, heating, and billing errors. The problem of dining time (first or second seating) at a restaurant, table size, and table mate is solved by asking the restaurant's maitre $\mathrm{d}^{\prime}$ for help. In addition, free motion sickness pills are provided at the front office for passengers who experience seasickness. Norovirus can be contracted through infected food and water, contact with the surface of an object or through human contact or excrement, resulting in abdominal pain, vomiting, diarrhoea, dizziness, and/or headaches [75]. The Diamond Princess, which suffered from a norovirus outbreak in 2014, infected 158 more people in 2016. When about 60 people were infected with norovirus in 2014 , they tried to minimize the number of infected passengers by adding sanitary procedures, such as quarantine measures for about 50 cabins and suspending self-service, but the rest of the passengers had to give up visiting ports. Although boarding was delayed for about four hours for in-vessel sterilization before starting the next voyage, Princess immediately announced through a spokesman that the ship was fully sanitized, but said no compensation or refund was possible except for infected passengers, forcing passengers on the next voyage to board because they could not get a refund for the hundreds of dollars already paid. In addition, the Diamond Princess cruise ship was quarantined in Yokohama, Japan, in February 2020 amid a COVID-19 outbreak that sickened 712 (19\%) of the 3711 passengers, killing 13 . Cruise ships are a unique, confined environment that simulate the living 
conditions and social interactions of a city and are filled with people of different ethnicities, as well as immunization and health statuses. The proximity of passengers and crew members in a semi-enclosed shipscape, with interactions in the dining rooms, entertaining facilities, spas, and pools, creates a unique environment for the person-to-person transmission of microbes [76]. Along with an improvement of the ventilation system, stronger disinfectants, careful cleaning, personal hygiene by passengers, and stricter quarantine protocols must be implemented. The occurrence of problems on ships impact cruise line reputations, making it necessary to notify passengers quickly. If an outbreak or other problem is mishandled, the cruise line's reputation will be severely damaged by word of mouth. Certainly, the recent spate of negative publicity involving several cruise ships during the COVID-19 pandemic will undoubtedly affect the public's perception of cruise safety [77]; therefore, cruise companies must improve their service processes to ensure high quarantine standards and automate systems to enhance their reputation [29].

The sinking of the Costa Concordia in January 2012 is a representative event that had a significant impact on the reputation of the world's largest cruise company, Carnival Corporation. Thirty-two passengers were killed and 64 were injured. At that time Captain Sketino and his crew were arrested after they were found to have given up the ship and evacuated with passengers still onboard. In addition to losing its existing reputation as Europe's most historic and popular cruise line, Costa Cruises was hit hard by a EUR 1 million fine for its responsibility for the accident and the EUR 450 million cost for the ship itself. In addition to compensation, survivors of the Concordia disaster called for safety improvements to be made. It was clear that the initial grounding of the Costa Concordia could have been avoided and that subsequent failings in carrying out the evacuation process made an unbelievably bad situation far worse [78]. On the other hand, Costa Victoria's rescue of $12 \mathrm{crew}$ members from a fishing boat that caught fire while travelling from the South China Sea to a Sanya port in Hong Kong in November 2014 showed the crew's ability to rescue emergency workers and respect for life, raising the credibility of the ship's crew.

Cruise Minus [74], which deals with cruise-related incidents, reported that cruise-related incidents/accidents include disasters such as sinking, being stranded, rollover, collisions, mechanical accidents including ship fires, air and sea pollution accidents, and incidents like fog, typhoons, gusts, and viruses. Jim Walker [79], a lawyer specializing in cruise-ship-related crimes and passenger safety, said the problem with images and reputations does not stem from accidents such as ship fires or sinking, but rather from the handling of various incidents on the ship: poor crew treatment problems, sexual crimes or child abuse by crew members, missing passengers, the environment, and water pollution. An attitude of respect for laws and procedures is required to prevent incidents that undermine the cruise line's reputation, and it is said that the safety and interests of passengers should be protected as quickly as possible after accidents and incidents.

The hours and information of operation of facilities and programs on the vessel are announced to passengers through shipboard newspapers and broadcasting systems and may be subject to change by ship circumstances. A passenger's personal information, reservation information, and purchase information are managed through the cabin account as a record of passengers. This personal information includes the passenger's name and nationality, reservation information, the class and membership of the passenger cabin, additional services and shore excursions, and details of onboard purchases [75]. 
Table 4. Reliability.

\begin{tabular}{|c|c|c|c|c|}
\hline Quality Item & Costa Victoria & $\begin{array}{l}\text { Diamond } \\
\text { Princess }\end{array}$ & Superstar Virgo & Finding \\
\hline $\begin{array}{l}\text { Itinerary and } \\
\text { Departure/Arrival time } \\
\text { compliance }\end{array}$ & $\begin{array}{l}\text { They can change the } \\
\text { itinerary and onboard } \\
\text { program; they only } \\
\text { refund in case of } \\
\text { changes because of } \\
\text { cruise line's one-sided } \\
\text { reasons providing } \\
\text { substitutive } \\
\text { services/compensation }\end{array}$ & Same & Same & $\begin{array}{l}\text { Not liable for changing } \\
\text { itineraries and onboard } \\
\text { programs; they usually } \\
\text { provide substitutive } \\
\text { services or } \\
\text { compensations for } \\
\text { customer satisfaction } \\
\text { case by case }\end{array}$ \\
\hline $\begin{array}{l}\text { When customers have } \\
\text { problems, the cruise } \\
\text { ship is sympathetic } \\
\text { and reassuring }\end{array}$ & $\begin{array}{l}\text { Passenger-Crew ratio } \\
(\mathrm{PCR})(2.8: 1)\end{array}$ & $\begin{array}{l}\text { PCR }(2.5: 1) \\
\text { Handling of } \\
\text { various incidents }\end{array}$ & PCR (2.2:1) & $\begin{array}{l}\text { The attitudes for } \\
\text { solving customer } \\
\text { problems affect a cruise } \\
\text { line's reputation }\end{array}$ \\
\hline $\begin{array}{l}\text { Cruise ship is } \\
\text { dependable }\end{array}$ & $\begin{array}{l}\text {-Europe No. } 1 \text { Cruise } \\
\text { ·For more than } 65 \text { years } \\
\text { the historic Costa } \\
\text { Cruises brand has been } \\
\text { providing the best of } \\
\text { Italian hospitality. } \\
\text {-Costa Concordia } \\
\text { disaster; Rescue of } \\
\text { passengers from a } \\
\text { fishing boat on fire }\end{array}$ & $\begin{array}{l}\text { Premium cruise } \\
\text { with innovative } \\
\text { ships, an array of } \\
\text { onboard options, } \\
\text { and an } \\
\text { environment of } \\
\text { exceptional } \\
\text { customer service } \\
\text {-Norovirus, } \\
\text { COVID-19 }\end{array}$ & $\begin{array}{l}\text {-The Leading Cruise } \\
\text { Line in the Asia Pacific } \\
\text {-Star Cruises has built } \\
\text { its reputation on } \\
\text { offering first-rate Asian } \\
\text { hospitality throughout } \\
\text { its fleet of six vessels } \\
\text {-No accidents }\end{array}$ & $\begin{array}{l}\text { The cruise line's } \\
\text { reputation is not just } \\
\text { because of ship fires, } \\
\text { Concordia-like } \\
\text { disasters; continuous } \\
\text { records about } \\
\text { environmental } \\
\text { pollution, } \\
\text { mistreatment of crew } \\
\text { members, PR response } \\
\text { and follow-up } \\
\text { reactions }\end{array}$ \\
\hline $\begin{array}{l}\text { Cruise onboard } \\
\text { programs on time }\end{array}$ & $\begin{array}{l}\text { Announcements for } \\
\text { daily schedules and } \\
\text { programs }\end{array}$ & $\begin{array}{l}\text { Announcements } \\
\text { for daily } \\
\text { schedules and } \\
\text { programs }\end{array}$ & $\begin{array}{l}\text { Announcements for } \\
\text { daily schedules and } \\
\text { programs }\end{array}$ & $\begin{array}{l}\text { Facilities opening and } \\
\text { program operation on } \\
\text { time }\end{array}$ \\
\hline $\begin{array}{l}\text { Cruise ship keeps its } \\
\text { records accurately }\end{array}$ & $\begin{array}{l}\text { Handling of Personal } \\
\text { data (ID information, } \\
\text { reservation } \\
\text { information-cabin } \\
\text { categories, } \\
\text { membership, } \\
\text { additional services, } \\
\text { shore excursions, } \\
\text { purchases (invoice)) }\end{array}$ & Same & Same & $\begin{array}{l}\text { Cruise ships keep } \\
\text { personal records (Id, } \\
\text { reservations, } \\
\text { purchases) accurately }\end{array}$ \\
\hline
\end{tabular}

\subsubsection{Responsiveness}

Responsiveness is related to the willingness or readiness of the staff to provide service and the timeliness of the service. In the case of a cruise, the crew's immediate commitment to service, voluntary customer support posture, and crew members who respond quickly to customers' needs, no matter how busy they are, are closely related to the time they promise to provide services including boarding, disembarking procedures, and baggage handling (Table 5).

Cruise embarkation usually takes place six hours before departure, and the exact time is announced before boarding. During the boarding process, passengers receive the Seapass. Once issued and boarding procedures are completed, passengers can enter the ship through the gangway after passing the X-ray and finally board.

As for the disembarkation procedure, on the day before disembarkation, if a tag classified by colour and number is delivered to the cabin according to the disembarkation order, the passenger attaches it to the baggage and leaves it outside the cabin door. After arriving at the disembarkation port, they move to the port terminal. Passengers settle their purchases on board the ship and leave the port in order according to the broadcast announcement to find their baggage stored at the port terminal. These procedures provide (a) smooth progression in embarkation and disembarkation, (b) baggage 
delivery to the cabin after embarkation, and (c) baggage retrieval at the terminal after disembarkation and are all related to the responsiveness of the service. On the day of disembarkation, the cabin must be emptied early in the morning for the next voyage passenger, so if the disembarkation procedure is delayed, passengers waiting for disembarkation will have no choice but to spend time at the bar or lounge. Therefore, some cruise lines provide simple drinks and snacks. In the case of the comparison vessels, there was no record of providing compensation services due to delays in disembarkation procedures [80].

There are two main types of baggage loss: when the airline loses baggage in the process of transport or when the baggage is left to the porter before check-in at the boarding port but does not arrive in the cabin. When this happens, crew members inform the airline of the reservation information (cruise ship name, schedule) of the ship to be boarded, and passengers inform the front office of the same after boarding so that the baggage can be found at another port during the itinerary. Baggage delivery may be delayed depending on the size of the ship and the number of people on board, so passengers are asked to endure the delivery time of a few hours after departure. However, Superstar Virgo promises to deliver baggage at least $60 \mathrm{~min}$ after departure. If the baggage does not arrive in the cabin after a few hours, it will be tracked at the front office. Delays are mostly due to baggage delivered incorrectly to another cabin or when the bag contains prohibited items such as metal, candles, or smuggled liquor. Cruise lines endeavour to promptly find lost baggage and try to relieve passengers' inconvenience by providing amenity kits consisting of essential items necessary for life on board [75,79].

Purchases on board can be paid with the Seapass issued at the time of boarding, and the receipt is signed by hand after the purchase is stored and used as evidence for confirmation of settlement details before disembarkation. Cancellation is made immediately if there is no problem with the product. All ships operate a $24-\mathrm{h}$ front office and room service, realizing timely service. Costa provides room service for free for suite and premium cabin passengers and charges a fee for regular passengers; Princess offers free room service, while Star's room service is not free. The crew cleans the cabin twice a day and immediately responds to customer complaints, such as by providing an exchange of amenities. However, most complaints within the ship are funnelled through the front office, and when customer inquiries are concentrated, processing is delayed. To improve responsiveness, Princess introduced onboard web services called Princess@sea, interactive TV, and onboard kiosks, and it operates them for free. These provide information on onboard programs, restaurant menu, facility operation information, ship sailing schedule and port guide (shopping for shore excursions and tourism information, etc.), as well as a messenger service that can be used to communicate with other passengers on board. It is even possible to directly check the details of the passenger's onboard account, reducing the number of passengers waiting at the front office [63-65].

Table 5. Responsiveness.

\begin{tabular}{|c|c|c|c|c|}
\hline Quality Item & Costa Victoria & $\begin{array}{l}\text { Diamond } \\
\text { Princess }\end{array}$ & Superstar Virgo & Finding \\
\hline $\begin{array}{l}\text { They do not tell } \\
\text { customers exactly } \\
\text { when services will } \\
\text { be performed (-) }\end{array}$ & $\begin{array}{l}\text { No time assurance } \\
\text { for baggage } \\
\text { delivery }\end{array}$ & Same as Costa & $\begin{array}{l}\text { Check-in baggage } \\
\text { delivery to the } \\
\text { cabins no later than } \\
60 \text { min after sailing }\end{array}$ & $\begin{array}{l}\text { They do not tell } \\
\text { customers exactly } \\
\text { when check-in/out } \\
\text { and baggage } \\
\text { delivery services } \\
\text { will be performed } \\
\text { and finished }\end{array}$ \\
\hline
\end{tabular}


Table 5. Cont.

\begin{tabular}{|c|c|c|c|c|}
\hline Quality Item & Costa Victoria & $\begin{array}{l}\text { Diamond } \\
\text { Princess }\end{array}$ & Superstar Virgo & Finding \\
\hline $\begin{array}{l}\text { You do not receive } \\
\text { prompt service } \\
\text { from crew } \\
\text { members (-) }\end{array}$ & $\begin{array}{l}\text {-Receipts issued } \\
\text { promptly after } \\
\text { purchasing on } \\
\text { board } \\
\text {-Refund } \\
\text { immediately after } \\
\text { cancellation } \\
\text { purchasing }\end{array}$ & Same & Same & $\begin{array}{l}\text {-Immediate } \\
\text { reaction after } \\
\text { customer requests }\end{array}$ \\
\hline $\begin{array}{l}\text { Crew members are } \\
\text { not always willing } \\
\text { to help customers } \\
(-)\end{array}$ & $\cdot \operatorname{PCR}(2.8: 1)$ & $\cdot \operatorname{PCR}(2.5: 1)$ & ·PCR (2.2:1) & $\begin{array}{l}\text { Spontaneous } \\
\text { customer support } \\
\text {-Improving PCR } \\
\text { ratio }\end{array}$ \\
\hline $\begin{array}{l}\text { Crew members are } \\
\text { too busy to } \\
\text { respond to } \\
\text { customer requests } \\
\text { promptly (-) }\end{array}$ & $\begin{array}{l}\cdot 24-h \text { Front office } \\
\text { service (room } \\
\text { service-nominal } \\
\text { fee/free) }\end{array}$ & $\begin{array}{l}\text { ·24-h Front office } \\
\text { service (room } \\
\text { service-nominal } \\
\text { fee) } \\
\text {-Interactive TV, } \\
\text { Kiosk, } \\
\text { Princess@sea }\end{array}$ & $\begin{array}{l}\cdot 24-h \text { Front office } \\
\text { service (room } \\
\text { service-nominal } \\
\text { fee) }\end{array}$ & $\begin{array}{l}\text { Stand ready for } \\
\text { customers } 24 \mathrm{~h} \\
\text {.Smart web service }\end{array}$ \\
\hline
\end{tabular}

\subsubsection{Assurance}

Assurance relates to employee competence, courteous attitude, trustworthiness, and safety. The assurance of cruise services is excellent safety records or safety-related notices and emergency evacuation drills, the polite and courteous attitude of crew members, and sufficient knowledge and communication to answer passenger questions, as shown in Table 6.

Costa, which suffered a major blow to the trust of the captain and crew in the 2012 Costa Concordia sinking, showed the ship crew's emergency rescue capabilities and respect for life in November 2014 when Costa Victoria rescued 12 crew members from a fishing boat that caught fire and quickly transported them to a Chinese Coast Guard helicopter after rendering first aid. In the case of Diamond Princess, emergency patients were quickly transported by helicopter in 2013 and 2015, and the crew's handling of emergencies added to the passengers' confidence in the crew. There is no record of any safety accidents related to the Superstar Virgo. This added assurance to crew members in the navigation and security department [74].

The International Maritime Organization (IMO) is a United Nations organization responsible for improving the safety on board all vessels, including cruise ships. It has developed rules and regulations for all officers and crews and specifies the minimum standards of safety for a ship to adhere to, such as the Safety of Life at Sea (SOLAS) and Standards of Training, Certification and Watchkeeping (STCW). All crew members on all cruise lines are obliged to hold a Basic Safety Training (BST) certificate, and they adhere to the principle that the safety of passengers and crew should be the top priority. Accordingly, on the day of departure, all crew members and passengers must participate in the Emergency Drill, as stipulated by the Safety of Life at Sea Convention (SOLAS). Emergency drills are announced through shipboard newspapers and broadcasting systems, and crew members help and guide passengers throughout the ship [81].

Princess has been running a C.R.U.I.S.E. (Courtesy, Respect, Unfailing in Service Excellence) program since 1996. The program also applies to all crew members, including the port of call service. A biweekly C.R.U.I.S.E. 'joggers' (education and briefing session) is also held, and all members attend once-a-month meetings to discuss the results of the CSQs (Customer Service Questionnaires) at the end of every cruise. All employees prepare and share a C.R.U.I.S.E. newspaper that contains information on service improvements. Costa recommends filling out the Customer Satisfaction Questionnaire on its 
website within 14 days after cruise, and Star also collects passengers' opinions through the Customer Feedback Form to improve its service, allowing the crew to face the passengers in a polite and polite manner [63-65].

Crew members of Costa and Princess are hired based on their related experience, such as more than two years of hotel experience. After recruitment, they are placed on board the ship to promote service expertise through intensive re-education. Costa's fire team is regularly sent to the training centre, which includes special training such as learning the skills to put out simulated fires and training in action from qualified professional instructors. In addition, Star Cruises operates its own crew training academy called GSTA (Genting-Star Tourism Academy) in Shanghai, which fosters the knowledge, skills, and attitudes required for passenger service, and it selects crew members upon completion of the prescribed course [71-73].

As Costa Victoria services passengers speaking various languages, employees speaking several languages take turns working at the front office, and, in case of a problem, they contact employees with the corresponding language to solve the problem. In general, all announcements on board are made in four or more languages. Because the Diamond Princess operates in Australia, New Zealand, and Northeast Asia, it mainly uses English and Japanese on board. Superstar Virgo's main customers are Chinese, Singaporeans, Indians, and other Asians, so Chinese and English are used as official languages on board the ship. The crew members of over 25 nationalities all speak English, and some are fluent in both Chinese and English. Therefore, in cruises where passengers of the most diverse nationalities are on board, communication can have a profound effect on the quality of service, so language skills are essential for crews, and intensive training is provided for each task on board.

Table 6. Assurance.

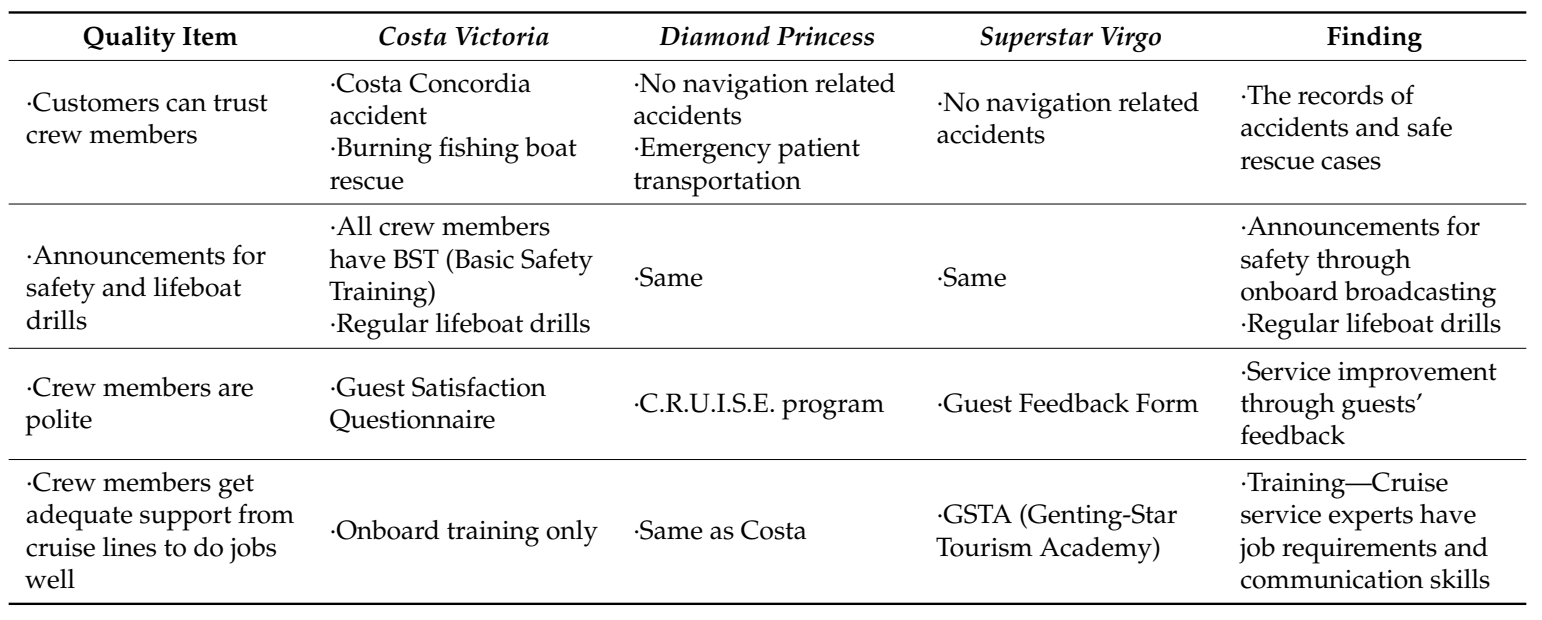

\subsubsection{Empathy}

Empathy is trying to understand customer needs, and it emphasizes the effort to care for each customer. The empathy of the cruise service is the individual interest in the passengers, whether the business hours are adjusted for the convenience and consideration for the individual passengers, whether the interests of the passengers are sincerely considered, and whether the crew understands the needs of the passengers (Table 7).

It is true that Costa Victoria and Superstar Virgo operate short itineraries (1-7 nights) on Asian routes, and about 2000 passengers are replaced in short cycles, making it difficult to pay individual attention to each passenger. Even though the Diamond Princess schedule is relatively long (7 days or longer), all three cruises are open only for a limited period of time, except for the front office, so customers must visit within business hours. All of them operate a 24-h front office to improve accessibility for customers, and 24-h room service is also provided. It is common for cruise lines to offer memberships that recognize regular customers and provide benefits according to frequency of 
use, and they host membership parties on board to present badges or letters of appreciation and to meet member passengers.

Despite the limited business hours of onboard public facilities, the cruise lines offer a variety of dining options. Costa Victoria encourages passengers to dine where they want among two dining restaurants, buffet restaurants, pizzeria, and a la carte. However, in the case of dinner restaurants, a table is assigned to each passenger's cabin and it must be utilized throughout the cruise. In the case of Superstar Virgo, there are a variety of dining options available: a dinner restaurant, a buffet, or a paid specialty restaurant, including midnight snacks. Diamond Princess operates an 'anytime dining' system to provide another option for passengers to visit and dine within the operating hours, which allows them to visit at any convenient time.

For the crew's consideration of the individual passengers, when special dining is requested, it is prepared and quickly expedited. For passengers who need special diets, such as vegetarian and diabetic, Costa Cruises will prepare the food if they inform the crew before or after boarding. Every Diamond Princess menu includes vegetarian meals, especially in the restaurants, where crew members are responsible for fixed table areas, so they try to recognize and remember individual passenger tastes and reflect them in the service.

The port tour guides determine the difficulty levels of activities, accessibility for wheelchair passengers, and language of the guide in advance to assist in the selection, considering the individual circumstances of the passenger. When a wheelchair passenger participates in a tour, the crew escorts the passenger directly, depending on the circumstances.

Evidence that cruises take the personal interests of the passengers seriously can be found in the benefits of membership. In the case of Costa Cruises, the membership system called Costa Club is operated in six stages, including Ambra, Aqua Marina, Corallo, Perla, Perla Oro, and Perla Diamant; benefits of membership include cabin upgrades, priority boarding and disembarkation, baggage delivery, VIP lounge access, and premium amenities. Princess Cruise offers four levels of preferential treatment: Gold, Ruby, Platinum, and Elite ratings; the benefits include free internet access, priority check-in and boarding, free wine tasting; cabin upgrades; free minibars, and free laundry and shoe polishing services. Star Cruise operates five levels of membership, including Star, Classic, Silver, Gold, and Platinum, with priority boarding and disembarkation, priority reservation for various shows and events, invitation to member events, up to $50 \%$ discount on cabin fare, and purchases on board. In particular, the customer department (VIP department) for casinos is separately operated to carry out various promotions, and there are game points that are awarded according to the amounts and number of bets, so passengers can receive cabin support benefits. In addition, operating a game room that gives qualifications according to game points provides a service that responds to customer needs, allowing customers to fully enjoy the casino on a ship separated from their daily life [63-65].

Costa Victoria operates a tipping policy for adult passengers at USD 12.50 (EUR 10) per person per day; the rate is $50 \%$ for children aged 4-14, and it is free for children aged 0-3. Diamond Princess's daily gratuity is USD 16.50 per guest for suites, USD 15.50 per guest for mini-suites, and USD 14.50 per guest (including children) in all other staterooms; this charge is automatically added to each passenger's shipboard account on a daily basis. Superstar Virgo operates an unconventional policy that does not require tips in consideration of the cultural peculiarity that Asian passengers, the main customers, are unfamiliar with tipping policies. Costa Victoria, which is widely used as a charter ship in China and Korea, is actively responding to various demands by considering characteristics of passengers. Superstar Virgo has a dedicated group coordinator to flexibly provide various services according to the group personality [63-65].

Because of the nature of the cruise service industry, where passengers and crew members of various nationalities meet in a cruise ship, it is difficult to understand and accommodate all the individual needs of passengers. However, more than anything else, it is necessary to understand these differences from the perspective of the passengers and value their interests through friendly service based on smooth communication and understanding of individual passenger characteristics. 
Table 7. Empathy.

\begin{tabular}{|c|c|c|c|c|}
\hline Quality Item & Costa Victoria & Diamond Princess & Superstar Virgo & Finding \\
\hline \multirow{2}{*}{$\begin{array}{l}\text { Cruise lines do not give } \\
\text { customers individual } \\
\text { attention }(-)\end{array}$} & $\begin{array}{l}\text { 24-h room service } \\
\text { (nominal charge/free) }\end{array}$ & 24-h room service (free) & $\begin{array}{l}\text { 24-h room service } \\
\text { (nominal fee) }\end{array}$ & \multirow{2}{*}{$\begin{array}{l}\text { Stand ready for } \\
\text { customer's needs } 24 \mathrm{~h} \text { a } \\
\text { day } \\
\text { Membership: customer } \\
\text { relationship } \\
\text { management }\end{array}$} \\
\hline & Membership (6 levels) & Membership (6 levels) & Membership (5 levels) & \\
\hline $\begin{array}{l}\text { Crew members do not } \\
\text { give customers personal } \\
\text { attention (-) }\end{array}$ & 5 dining options & $\begin{array}{l}13 \text { dining options } \\
\text { Anytime dining }\end{array}$ & 4 dining options & $\begin{array}{l}\text { Several dining options, } \\
\text { though open hours of } \\
\text { onboard facilities are } \\
\text { limited }\end{array}$ \\
\hline $\begin{array}{l}\text { Crew members do not } \\
\text { know what customers' } \\
\text { needs are }(-)\end{array}$ & $\begin{array}{l}\text { Special dining request } \\
\text { Shore excursion option }\end{array}$ & Same as Costa & Shore excursion option & $\begin{array}{l}\text { Consider the customer's } \\
\text { individual dining } \\
\text { request and shore } \\
\text { excursion selection }\end{array}$ \\
\hline \multirow{2}{*}{$\begin{array}{l}\text { Cruise lines do not have } \\
\text { customer's best interests } \\
\text { at heart (-) }\end{array}$} & $\begin{array}{l}\text { Membership (6 levels) } \\
\text { benefits }\end{array}$ & $\begin{array}{l}\text { Membership (4 levels) } \\
\text { benefits }\end{array}$ & $\begin{array}{l}\text { Membership (5 levels) } \\
\text { benefits }\end{array}$ & \multirow{2}{*}{$\begin{array}{l}\text { Provide benefits through } \\
\text { cruise membership and } \\
\text { next cruise promotion }\end{array}$} \\
\hline & Cruise fare promotion & Next cruise promotion & $\begin{array}{l}\text { Casino membership } \\
\text { promotion }\end{array}$ & \\
\hline \multirow{2}{*}{$\begin{array}{l}\text { Cruise lines do not have } \\
\text { operating hours } \\
\text { convenient for all their } \\
\text { customers (-) }\end{array}$} & $\begin{array}{l}\text { Charter/group guests } \\
\text { caring }\end{array}$ & $\begin{array}{l}\text { Charter/group guests } \\
\text { caring }\end{array}$ & Group guests caring & $\begin{array}{l}\text { Respond to special } \\
\text { requests, understanding } \\
\text { customer's specifics }\end{array}$ \\
\hline & $\begin{array}{l}\text { Tipping (Adult: USD } \\
\text { 12.00, 4-14: 50\%, 0-3: } \\
\text { Free) }\end{array}$ & Tipping (USD 14.50) & No tipping policy & Tipping policy \\
\hline
\end{tabular}

\section{Discussion and Conclusions}

\subsection{Summary}

This study selected the Costa Victoria, Diamond Princess, and Superstar Virgo as ships with similar specifications that operate in Asia, and it derived a cruise SERVQUAL to evaluate each ship. Then, a comparative analysis was performed. The environment for each cruise attribute that influences the selection and use of ships from the perspective of consumers was understood and practical implications provided.

The Diamond Princess had the highest SERVQUAL score among the three cruise ships. The implications through detailed analysis are as follows. First, ships on Asian routes are only medium-sized and are obsolete, but the introduction of mega (jumbo) ships is in line with the trend of increasing ship size. Regular inspections for ship sanitation are required. Cruise lines must thoroughly supervise the management of ships to reflect the cruise line concept, marketing points, and characteristics and demands of the target customer base by monitoring quality service. In recent decades, the size of cruise ships has increased considerably, in line with mass family tourism trends. As a result of this 'giantism', the Royal Caribbean's oasis-class ships (which are among the world's largest) can cost up to USD 140 million; therefore, investments should be made based on the market situation and demand. Abundant facilities, onboard activities, and fascinating scenery should be provided to attract passengers [82]; however, it is also worth noting the increased customer scepticism of large ships following the COVID-19 outbreak.

Second, in the cruise service process, reliability is key to accurately complying with the promised sailing and operating schedule for onboard activities. However, because of the nature of cruise tourism, which is affected by various external variables, including weather, an alternative is needed. Therefore, cruise lines must minimize passenger dissatisfaction by providing alternative services or compensation, even if the itineraries change in consideration of passenger safety. In addition, since management attitudes toward passenger problems have a great impact on the reputation of ships and cruise ships, with brand reputation and recognition affecting customer behaviour [83], the cruise industry should proactively address health-related concerns such as the norovirus and Covid-19. A unique quarantine protocol considering the cruise shipscape must be implemented, and sailing must 
be completed. Österman et al. [84] noted that 'the service crew is a vital part of the customer experience on board passenger ships and also has important safety duties in case of emergencies'. Therefore, precautionary measures are as important for crew members as they are for passengers. As a result of the COVID-19 pandemic, the cruise industry is expected to develop standard protocols for future cruises and take more stringent medical measures, such as disinfection robots and individual dishes that meet hospital health standards, as well as regular temperature checks, onboard medical centre upgrades, improvement of air purification systems, and confirmation of essential health certificates for elderly travellers. In addition, COVID-19 has resulted in the tourism industry as a whole adhering to stricter health standards; automation and digital cleaning systems will also be a future trend [29].

Third, responsiveness can be summarized as 'the crew's timely response to customers in the cruise service process'. That is, in order to improve customer responsiveness, it can be inferred that improving the ratio of crew members to passengers (PCR) to relatively increase the responsiveness to passengers will help improve service quality. To increase the responsiveness of the crew in each business area, the PCR should be increased as much as possible. The introduction of a smart service system would be useful. To increase customer responsiveness, onboard kiosks and in-cabin interactive TVs should be expanded to enable passengers to make reservations or purchases smoothly from their accounts. Staff responsiveness should be improved through the use of various communication channels (e.g., interpersonal conversations, social media, text messages, apps, etc.). Improving the passenger-to-crew ratio can also increase the frequency of interactions with customers, allowing passengers to receive timely and careful service as well as providing a prompt response to service recovery. Quality professional services should be maintained by ensuring that employees can provide prompt and appropriate services through the appropriate interaction system on cruise lines. By providing passengers with user-friendly and relevant technologies (e.g., wearable devices, interactive screens, AI, etc.) to enhance service excellence, the cruise ship company can enhance the cruise experience [7].

Fourth, in terms of assurance, it is important to earn the trust of passengers by consistently managing voyage-related safety records and reassuring customers through broadcast announcements or emergency evacuation drills. It is possible to maintain a polite and courteous attitude in crew members through various activities, including collecting public opinions for service improvement and training and deploying professional personnel fluent in the relevant language for each route, in consideration of the various nationalities of the main customer base of each ship. Hence, it is necessary to have a system for nurturing professionals suitable for the service level of cruise lines. In addition, the crew manager must respect the 'cruise life' of the crew, as cruise ship employees are aware that they have other employment options and can easily be replaced; satisfaction in their relationships with friends and colleagues is paramount. Living and working on a cruise ship is a lifestyle, but those who work and live in international waters do not survive alone, and social support is strengthened by strengthening relationships with friends and family when 'their needs relatedness' are met [85]. Therefore, when considering the 'cruise life' of the crew in terms of internal marketing, the crew manager should understand the environment of dependence on each other and take care of them.

Fifth, in terms of empathy, the crew needs a customer-oriented attitude of service to consider passengers who alternate boarding in a short period of time by communicating smoothly. Additionally, they should consider individual customers by improving and expanding various promotions and membership systems. The customer evaluates, creates, and adds value in a given service, and the employee becomes more successful through the customer's participation. In other words, communication between passengers and employees satisfies passengers' emotional needs, and an environment that fosters effective communication can enhance positive awareness of service quality and purchase value [86].

From a practical point of view, this study suggests that, in designing the navigation service of a new cruise ship, cruise lines should consider service quality in addition to destination and itineraries. Therefore, executives of cruise ships are required to recognize the importance of constant inspection 
and improvement of cruise service quality in managing repeat customers as well as first-time customers and pay careful attention to overall service operation.

Tourists travelling in the post-COVID-19 era will be reluctant to participate in large-scale tours, and will, instead, prefer planned trips with an emphasis on extended experiences and holidays; the concept of 'slow tourism' is slowly taking root among tourists. Slow tourism focuses on the local population, long-term stays, and better experiences, with tourists prioritizing the quality of travel over quantity. After COVID-19, potential tourists are likely to express a renewed interest in the hygiene and cleanliness of travel destinations, medical facilities, and population density (including of locals and visitors) when making travel-related decisions [87]. Therefore, some argue that the cruise industry will experience a transition from Mass Cruise to Niche Cruise (NCTI) for the sustainability of the industry. A demand for greater economic benefits and lighter infrastructure through reduced mobility and changes in the cruise tourism paradigm; a transition to more environment-friendly small ships; the enhancement of regional mobility through the development of local cruise ships; and the promotion of the resilience of transportation structure and the tourism industry are some of the measures that can help the cruise industry survive in the post-COVID-19 world [25].

International cooperation for public health preparedness is a worldwide challenge. In a closed environment, cruise ships crossing the sea with passengers and crew of various nationalities are inherently international; therefore, the international community as a whole should regard the COVID-19 epidemic as a universal human issue and resolve its difficulties through mutual cooperation. For this, it is necessary to optimize quarantine conditions, considering the quality of life of those who are isolated, and ensure transparency in information disclosure. Given that cruise ships are 'small international societies', it is time for the cruise industry to call for international cooperation and global justice [68].

\subsection{Limitations and Future Research}

This study presents a strategic direction for cruise lines by comparing and analysing the cases of three ships with similar specifications using the cruise SERVQUAL model and deriving implications. However, there is a limitation in that the empirical applicability of each item of cruise service quality could not be verified, so an empirical study that measures the subdivided service quality each cruise provides to its passengers can be an opportunity for future research. In addition, we tried to present implications based on cases of industry failure, but the research conditions were poor due to the loss of the data sources for defunct cruise lines. We attempted in-depth interviews for scientific verification of the findings; however, the COVID-19 pandemic made this difficult due to limitations relating to personal contact. In addition, there are areas where the classification of service quality factors, in terms of reliability and certainty, is ambiguous, and further discussion is required through future studies.

Author Contributions: Conceptualization, K.C.C.; Investigation, Y.Y.; Writing-original draft preparation, Y.Y.; Writing-review and editing, K.C.C. Both authors have read and agreed to the published version of the manuscript.

Funding: This research was supported by Youngsan University research grant 2020.

Conflicts of Interest: The authors declare no conflict of interest.

\section{References}

1. Papathanassis, A. The growth and development of the cruise sector: A perspective article. Tour. Rev. 2019, 75, 130-135. [CrossRef]

2. Chen, J.M.; Nijkamp, P. Itinerary planning: Modelling cruise lines' lengths of stay in ports. Int. J. Hosp. Manag. 2018, 73, 55-63. [CrossRef]

3. Cruise Market Watch Website. Available online: https://cruisemarketwatch.com/growth (accessed on 21 August 2020).

4. CLIA. 2018 Asia Cruise Industry Ocean Source Market Report; Cruise Line International Association: Washington, DC, USA, 2018; pp. 1-31. 
5. CLIA. 2019 Asia Cruise Deployment \& Capacity Report; Cruise Line International Association: Washington, DC, USA, 2019; pp. 1-27.

6. Bake, D.A. Exploring Cruise Passengers' Demographics, Experience, and Satisfaction with Cruising the Western Caribbean. Int. J. Tour. Hosp. Rev. 2015, 1, 23. [CrossRef]

7. Kang, J. Identifying antecedents and consequences of well-being: The case of cruise passengers. Tour. Manag. Perspect. 2020, 33, 100609. [CrossRef]

8. Chua, B.; Lee, S.; Goh, B.; Han, H. Impacts of cruise service quality and price on vacationers' cruise experience: Moderating role of price sensitivity. Int. J. Hosp. Manag. 2015, 44, 131-145. [CrossRef]

9. Lee, B. The effect of gamification on psychological and behavioral outcomes: Implications for cruise tourism destinations. Sustainability 2019, 11, 3002. [CrossRef]

10. Li, X.R.; Petrick, J.F. Examining the antecedents of brand loyalty from an investment model perspective. J. Travel Res. 2008, 47, 25-34. [CrossRef]

11. Papathanassis, A.; Beckmann, I. Assessing the 'Poverty of cruise theory' Hypothesis. Ann. Tour. Res. 2011, 38, 153-174. [CrossRef]

12. Vega-Muñoz, A.; Arjona-Fuentes, J.M.; Ariza-Montes, A.; Han, H.; Law, R. In search of 'a research front' in cruise tourism studies. Int. J. Hosp. Manag. 2020, 85, 102353. [CrossRef]

13. Whyte, L.J. Cruise Tourists' Perceptions of Destination: Exploring Push and Pull Motivational Factors in the Decision to Take a Cruise Vacation. Ph.D. Thesis, University of Queensland, Brisbane, Australia, 2016.

14. Li, X.R.; Petrick, J.F. Towards an Integrative Model of Loyalty Formation: The Role of Quality and Value. Leis. Sci. 2010, 32, 201-221. [CrossRef]

15. Petrick, J.F. The Roles of Quality, Value, and Satisfaction in Predicting Cruise Passengers' Behavioral Intentions. J. Travel Res. 2004, 42, 397-407. [CrossRef]

16. Monferrer, D.; Segarra, J.R.; Estrada, M.; Moliner, M.Á. Service Quality and Customer Loyalty in a Post-Crisis Context. Prediction-Oriented Modeling to Enhance the Particular Importance of a Social and Sustainable Approach. Sustainability 2019, 11, 4930. [CrossRef]

17. Zhang, Z.; Ye, Q.; Song, H.; Liu, T. The structure of customer satisfaction with cruise-line services: An empirical investigation based on online word of mouth. Curr. Issues Tour. 2015, 18, 450-464. [CrossRef]

18. Bryce, K.R. The Role of Social Media in Crisis Management at Carnival Cruise Line. J. Bus. Case Stud. JBCS 2014, 10, 231-238. [CrossRef]

19. Dev, C.S. Carnival cruise lines: Charting a new brand course. Cornell Hotel Restaur. Adm. Q. 2006, 47, 301-308. [CrossRef]

20. Jones, P.; Hillier, D.; Comfort, D. The two market leaders in ocean cruising and corporate sustainability. Int. J. Contemp. Hosp. Manag. 2017, 29, 288-306. [CrossRef]

21. Kwortnik, R.J. Shipscape influence on the leisure cruise experience. Int. J. Cult. Tour. Hosp. Res. 2008, 2, 289-311. [CrossRef]

22. Di Vaio, A.; Varriale, L.; Lekakou, M.; Stefanidaki, E. Cruise and container shipping companies: A comparative analysis of sustainable development goals through environmental sustainability disclosure. Marit. Policy Manag. 2020, 1-29. [CrossRef]

23. Papathanassis, A. Cruise tourism management: State of the art. Tour. Rev. 2020, 72, 104-119. [CrossRef]

24. Sanz-Blas, S.; Buzova, D.; Schlesinger, W. The sustainability of cruise tourism onshore: The impact of crowding on visitors' satisfaction. Sustainability 2019, 11, 1510. [CrossRef]

25. Renaud, L. Reconsidering global mobility-distancing from mass cruise tourism in the aftermath of COVID-19. Tour. Geogr. 2020, 1-11. [CrossRef]

26. Hennigs, N.; Schmidt, S.; Wiedmann, K.P.; Karampournioti, E.; Labenz, F. Measuring brand performance in the cruise industry: Brand experiences and sustainability orientation as basis for value creation. Int. J. Serv. Technol. Manag. 2017, 23, 189-203. [CrossRef]

27. Könnölä, K.; Kangas, K.; Seppälä, K.; Mäkelä, M.; Lehtonen, T. Considering sustainability in cruise vessel design and construction based on existing sustainability certification systems. J. Clean. Prod. 2020, 259, 120763. [CrossRef]

28. Cruise Lines International Association. 2020 State of the Cruise Industry Outlook; Cruise Line International Association: Brussels, Belgium, 2020; pp. 1-25. Available online: https://cruising.org/news-and-research/ research/2019/december/state-of-the-cruise-industry-outlook-2020 (accessed on 16 September 2020).

29. Li, H.; Zhang, P.; Tong, H. The Labor Market of Chinese Cruise Seafarers: Demand, Opportunities and Challenges. Marit. Technol. Res. 2020, 2. [CrossRef] 
30. Parasuraman, A.; Zeithaml, V.; Berry, L. SERVQUAL: A Multiple-Item Scale for Measuring Consumer Perceptions of Service Quality. J. Retiling 1988, 64, 12-40.

31. Kim, S.; Holland, S.; Han, H. A Structural Model for Examining how Destination Image, Perceived Value, and Service Quality Affect Destination Loyalty: A Case Study of Orlando. Int. J. Tour. Res. 2012, 15, 313-328. [CrossRef]

32. Bojanic, D.C.; Drew Rosen, L. Measuring service quality in restaurants: An application of the SERVQUAL instrument. Hosp. Res. J. 1994, 18, 3-14. [CrossRef]

33. Saleh, F.; Ryan, C. Analysing Service Quality in the Hospitality Industry Using the SERVQUAL Model. Serv. Ind. J. 1991, 11, 324-345. [CrossRef]

34. Pizam, A.; Neumann, Y.; Reichel, A. Dimensions of tourist satisfaction with a destination area. Ann. Tour. Res. 1978, 5, 314-322. [CrossRef]

35. Chang, J. Taiwanese tourists' perceptions of service quality on outbound guided package tours: A qualitative examination of the SERVQUAL dimensions. J. Vacat. Mark. 2009, 15, 165-178. [CrossRef]

36. Frochot, J.; Hughes, H. HISTOQUAL: The development of a historic houses assessment scale Isabelle. Tour. Manag. 2000, 21, 157-167. [CrossRef]

37. Khan, M. ECOSERV: Ecotourists' Quality Expectations. Ann. Tour. Res. 2003, 30, 109-124. [CrossRef]

38. Tribe, J.; Snaith, T. From SERVQUAL to HOLSAT: Holiday satisfaction in Varadero, Cuba. Tour. Manag. 1998, 19, 25-34. [CrossRef]

39. Bitner, M.J.; Booms, B.H.; Tetreault, M.S. The Service Encounter: Diagnosing Favorable and Unfavorable Incidents. J. Mark. 1990, 54, 71-84. [CrossRef]

40. Wakefield, K.L.; Blodgett, J.G. Customer response to intangible and tangible service factors. Psychol. Mark. 1999, 16, 51-68. [CrossRef]

41. Lobo, A.C. Enhancing luxury cruise liner operators' competitive advantage: A study aimed at improving customer loyalty and future patronage. J. Travel Tour. Mark. 2008, 25, 1-12. [CrossRef]

42. Petrick, J.F. Segmenting Cruise Passengers with Perceived Reputation. J. Hosp. Tour. Manag. 2011, 18, 48-53. [CrossRef]

43. Yi, S.; Day, J.; Cai, L.A. Exploring Tourist Perceived Value: An Investigation of Asian Cruise Tourists' Travel Experience. J. Qual. Assur. Hosp. Tour. 2014, 15, 63-77. [CrossRef]

44. Brady, M.K.; Cronin, J.J., Jr. Some new thoughts on conceptualizing perceived service quality: A hierarchical approach. J. Mark. 2001, 65, 34-49. [CrossRef]

45. Bitner, M.J.; Booms, B.H.; Mohr, L.A. Critical Service Encounters: The Employee's Viewpoint. J. Mark. 1994, 58, 95-106. [CrossRef]

46. Wall, E.A.; Berry, L.L. The Combined Effects of the Physical Environment and Employee Behavior on Customer Perception of Restaurant Service Quality. Cornell Hotel Restaur. Adm. Q. 2007, 48, 59-69. [CrossRef]

47. Bitner, M.J. Evaluating service encounters: The effects of physical surroundings and employee responses. J. Mark. 1990, 54, 69-82. [CrossRef]

48. Baker, D.A.; Crompton, J.L. Quality, satisfaction and behavioral intentions. Ann. Tour. Res. 2000, $27,785-804$. [CrossRef]

49. Aggett, M.; Lim, W.M. Service Quality and the Cruise Industry. In The Business and Management of Ocean Cruise; Vogel, M., Papathanassis, A., Wolber, B., Eds.; CABI International: London, UK, 2012; Volume 3, pp. 154-196.

50. Petrick, J.F.; Tonner, C.; Quinn, C. The utilization of critical incident technique to examine cruise passengers repurchase intentions. J. Travel Res. 2006, 44, 273-280. [CrossRef]

51. Cruise Line International Association. Available online: http://www.akcruise.org/wp-content/uploads/2012/ 05/2011-CLIA-Lifestyle-Trends-Survey.pdf (accessed on 22 August 2020).

52. Xie, J.H.; Kerstetter, D.L.; Mattila, A.S. The attributes of a cruise ship that influence the decision making of cruisers and potential cruisers. Int. J. Hosp. Manag. 2012, 31, 152-159. [CrossRef]

53. Baxter, P.; Jack, S. Qualitative Case Study Methodology: Study Design and Implementation for Novice Researchers. Qual. Rep. 2008, 13, 544-559.

54. Eisenhardt, K.M. Building theories from case study research. Acad. Manag. Rev. 1989, 14, 532-550. [CrossRef]

55. Rowley, J. Using case studies in research. Manag. Res. News 2002, 25, 16-27. [CrossRef]

56. James, L.; Olsen, L.S.; Karlsdóttir, A. Sustainability and cruise tourism in the arctic: Stakeholder perspectives from Ísafjörður, Iceland and Qaqortoq, Greenland. J. Sustain. Tour. 2020, 28, 1425-1441. [CrossRef] 
57. Leposa, N. Problematic blue growth: A thematic synthesis of social sustainability problems related to growth in the marine and coastal tourism. Sustain. Sci. 2020, 15, 1233-1244. [CrossRef]

58. Bitektine, A. Prospective case study design: Qualitative method for deductive theory testing. Organ. Res. Methods 2008, 11, 160-180. [CrossRef]

59. Thomas, J.; Harden, A. Methods for the thematic synthesis of qualitative research in systematic reviews. BMC Med Res. Methodol. 2008, 8, 1-10. [CrossRef] [PubMed]

60. Yin, R.K. Case study Research: Design and Method, 3rd ed.; SAGE Publication: Thousand Oaks, CA, USA, 2003; pp. $40-41$.

61. Cruise Industry News. Asia-Pacific Market Briefing. Available online: https://www.cruiseindustrynews. com/store2/product/2014-2015-asia-pacific-market-briefing/ (accessed on 22 August 2020).

62. Esser, F.; Vliegenthart, R. Comparative Research Methods. Int. Encycl. Commun. Res. Methods 2017, 1-22. [CrossRef]

63. Costa Crociere. Available online: https://www.costacruises.eu/fleet.html (accessed on 22 August 2020).

64. Princess Cruises. Available online: https://www.princess.com/ships-and-experience/ships/ (accessed on 22 August 2020).

65. Star Cruises. Available online: https://www.starcruises.com/kr/en/ships (accessed on 25 January 2017).

66. Vogel, M. Pricing and Revenue Management for Cruises. In The Business and Management of Ocean Cruise; Vogel, M., Papathanassis, A., Wolber, B., Eds.; CABI International: London, UK, 2012; Volume 3, pp. 131-144.

67. CDC Vessel Sanitation Program. Available online: https://www.cdc.gov/nceh/vsp/default.htm (accessed on 25 January 2020).

68. Nakazawa, E.; Ino, H.; Akabayashi, A. Chronology of COVID-19 cases on the Diamond Princess cruise ship and ethical considerations: A report from Japan. Disaster Med. Public Health Prep. 2020, 1-8. [CrossRef] [PubMed]

69. Ito, H.; Hanaoka, S.; Kawasaki, T. The cruise industry and the COVID-19 outbreak. Transp. Res. Interdiscip. Perspect. 2020, 5, 100136. [CrossRef]

70. CDC: CDC's Role in Helping Cruise Ship Travelers during the COVID-19 Pandemic. Available online: https://www.cdc.gov/coronavirus/2019-ncov/travelers/cruise-ship/what-cdc-is-doing.html (accessed on 22 August 2020).

71. Costa Crociere Careers. Available online: https://career.costacrociere.it/ (accessed on 22 August 2020).

72. Princess Cruises Careers. Available online: https://www.princess.com/careers/ (accessed on 26 August 2020).

73. Star Cruises Careers. Available online: https://www.starcruises.com/us/en/careers (accessed on 22 August 2020).

74. Cruise Minus. Available online: https://www.cruiseminus.com (accessed on 22 August 2020).

75. CruiseCritic: Solving Cruise Problems: Onboard. Available online: https://www.cruisecritic.com/articles. cfm?ID=84 (accessed on 22 August 2020).

76. Center for Infectious Disease Research and Policy: COVID-19 Cruise Ship Studies Reflect Unique Disease Traits. Available online: https://www.cidrap.umn.edu/news-perspective/2020/06/covid-19-cruise-shipstudies-reflect-unique-disease-traits (accessed on 26 August 2020).

77. Hung, K.; Lee, J.S.; Wang, S.; Petrick, J.F. Constraints to cruising across cultures and time. Int. J. Hosp. Manag. 2020, 89, 102576. [CrossRef] [PubMed]

78. Costa Concordia Disaster. Available online: https://en.wikipedia.org/wiki/Costa_Concordia_disaster (accessed on 22 August 2020).

79. Cruise Law News. Available online: https://www.cruiselawnews.com (accessed on 22 August 2020).

80. CruiseCritic: Help! My Luggage Is Lost. What Should I Do? Available online: https://www.cruisecritic.com/ articles.cfm?ID=3940 (accessed on 22 August 2020).

81. IMO Safety Regulation: Passenger Ship. Available online: http://www.imo.org/en/OurWork/Safety/ Regulations/Pages/PassengerShips.aspx (accessed on 25 January 2020).

82. Castillo-Manzano, J.I.; López-Valpuesta, L. What does cruise passengers' satisfaction depend on? Does size really matter? Int. J. Hosp. Manag. 2018, 75, 116-118. [CrossRef]

83. Yu, J. Verification of the role of the experiential value of luxury cruises in terms of price premium. Sustainability 2019, 11, 3219. [CrossRef]

84. Österman, C.; Hult, C.; Praetorius, G. Occupational safety and health for service crew on passenger ships. Saf. Sci. 2020, 121, 403-413. [CrossRef] 
85. Radic, A.; Ariza-Montes, A.; Hernández-Perlines, F.; Giorgi, G. Connected at sea: The influence of the internet and online communication on the well-being and life satisfaction of cruise ship employees. Int. J. Environ. Res. Public Health 2020, 17, 2840. [CrossRef]

86. Jeong, J.Y.; Hyun, S.S. Roles of passengers' engagement memory and two-way communication in the premium price and information cost perceptions of a luxury cruise. Tour. Manag. Perspect. 2019, 32, 100559. [CrossRef]

87. Wen, J.; Kozak, M.; Yang, S.; Liu, F. COVID-19: Potential effects on Chinese citizens' lifestyle and travel. Tour. Rev. 2020. [CrossRef]

(C) 2020 by the authors. Licensee MDPI, Basel, Switzerland. This article is an open access article distributed under the terms and conditions of the Creative Commons Attribution (CC BY) license (http://creativecommons.org/licenses/by/4.0/). 